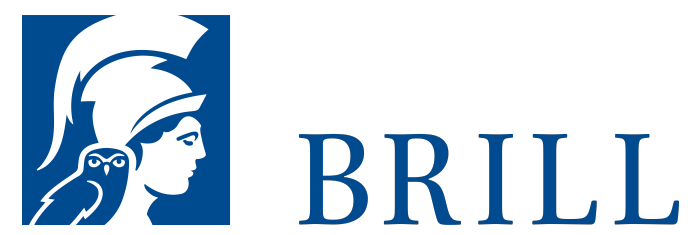

\section{Etymological Dictionary of the Armenian Inherited Lexicon}

\section{Author: Hrach Martirosyan}

As an Indo-European language, Armenian has been the subject of etymological research for over a hundred years. There are many valuable systematic handbooks, studies and surveys on comparative Armenian linguistics. Almost all of these works, with a few exceptions, mostly concentrate on Classical Armenian and touch the dialects only sporadically. Non-literary data taken from Armenian dialects have largely remained outside of the scope of Indo-European etymological considerations. This book provides an up-to-date description of the Indo-European lexical stock of Armenian with systematic inclusion of dialectal data. It incorporates the lexical, phonetic, and morphological material in the Armenian dialects into the etymological treatment of the Indo-European lexicon. In this respect it is completely new.

Readership

Indo-Europeanists as well as anyone interested in Armenian historical linguistics or etymological studies in general.

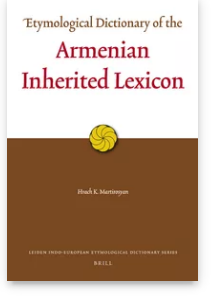

Pages: xvi, 988

pp.

Language:

English

Subjects:

Dictionaries,

Encyclopedias \&

Bibliographies,

Languages and

Linguistics,

Indo-European

Languages,

Languages and

Linguistics

Publisher: Brill

Series:

Leiden Indo-

European

Etymological

Dictionary

Series, Volume: 8

Hardback

Publication date:

23 Nov 2009

ISBN: 978-90-

o4-17337-8

List price

USD $\$ 335.00$ 
Hrach K. Martirosyan, Ph.D. (2008) in Comparative Linguistics, University of Leiden, has published several papers on Armenian etymology and dialectology.

For more information see brill.com

Order information: Order online at brill.com +44 330 333 0049 | customerservices@brill.com Submission information: brill.com/authors

Titles published by Brill | Fink, Brill | mentis or Brill | Schöningh: +49(o)71 5413279216 | brill@brocom.de 